\title{
Behavioral Factors Tend to Use the Internet Banking Services Case Study: System (SABA), the Melli Bank, Iran, Ardabil
}

\author{
Shahram Gilaninia (Corresponding author) \\ Department of industrial management, Rasht Branch \\ Islamic Azad University, Rasht, Iran \\ Tel: +98-911-335-6977_E-mail: gilani_sh45@yahoo.com
}

Arman Fattahi

Department of business management, Rasht Branch

Islamic Azad University, Rasht, Iran

Tel: +98-914-451-8123Ｅ-mail: arman_fattahi@yahoo.com

Seyyed Javad Mousavian

Department of Business management, Rasht Branch

Islamic Azad University, Rasht, Iran

Tel: +98-911-335-4617_E-mail:saba_moosaviyan@yahoo.com

Received: July 10, 2011 Accepted: July 21, $2011 \quad$ doi:10.5430/ijba.v2n3p173

\begin{abstract}
Electronic banking as the main elements of modern economy, it is a blessing of it world in which all financial activities, banking and credit of the traditional substrate is transferred to an electronic substrate. Internet communication channels are using one of the main requirements for banks to develop electronic banking services. The main purpose of this study identified various factors that influence behavior tends to use internet services by customers is internet banking. Therefore, cluster sampling method 384 questionnaires distributed among the customers of Melli bank branches (Ardabil, Iran) and collected. They were analyzed with ANOVA test. These results indicate that the impact of various factors on the orientation behavior (perceived ease, perceived usefulness, perceived security) to use internet services banking vary by customer.
\end{abstract}

Keywords: Internet Banking Services, Perceived Ease, Perceived Usefulness, Perceived Security

\section{Introduction}

Bank promotes savings and investment ventures within the economy. It intermediates between saver and borrower to accept surplus funds and lend money to deficient units.(Ahmad \& et al,2011). Today, most countries have been encouraged to use internet banking. The first half of the 90s using the internet and electronic data exchange has grown 23 percent annually and according to 2000 estimates, this growth has reached 36 percent. Now, use of instruments online payment in the world now has a thriving and the growing use of ATM, telephone and internet banking are 26, 25 and 35 percent respectively. While traditional methods and how to carry out banking transactions from branches has been to less than 10 percent. Iran in the field of e-commerce and internet as result internet banking, ranking 58th as a result the world (moradian, 2004). With the rapid development of internet and e-commerce and financial and banking sector, customers are encouraged to use online banking (yiu etal,2007). With the development of electronic systems such as internet and expand the use of cell phones in public financial institutions and banks were also affected. World Wide Web is basically the customers' expectations have changed about the speed, precision, price and service. Geographical distance has lost its meaning and availability, ease and speed of service delivery creates a competitive advantage for organizations, including banks. Businesses are forced to compete in this complex environment, the newest and most exciting services that customers want tools that are available to them. Banks in order to survive competition in bank branches are required to change the way from traditional banking desire and interests of the customer based on a new form of internet-based 
competition, reduce costs, retain customers, encourage customer, acceptance of customer (admissibility), security, ease of use, is part of a wide range of products and services (Chang, 2006).

\section{Theoretical Framework for Research}

The modern banking system has got the attention of all the people in the world in the 1970s. (Alam,2011) One of the modern internet technologies is internet banking. Bank of America SFNB large banks - the first true internet bank that opened October 18, 1995 in order to do business. It paved the way for the development of internet banking. Thoroughly believe that internet banking has created great competition in the banking relationship and also great opportunities to solidify relationships with customers, banks have provided that only profitability will not only consider. These views will ensure the future development of internet banking. The internet is the way to new opportunities for banks to expand their visibility and customer-oriented and the range of choices for their customers increased to use the banking system (Abasinejad, 2006). Need to identify factors that affect the tendency of people to use internet banking service is required, the banking industry help in developing marketing strategies to promote new forms of electronic banking systems to meet customer needs. (Wang, etal,2003) the benefits of electronic banking customers and financial institutions can be considered two aspects. From the perspective of customers, can save costs, save time access to multiple channels for operations of the bank named .from the perspective financial institutions, because these two features can be increased, banks in the present reputation for innovation, customer retention, despite the shift, creating an opportunity to search for new customers in target markets, geographic expansion, competitive activities and to establish the full circumstances (Bayat, 2008). This research based on development model with an additional adjustment of the technology, Davis, tells the story of perceived security according to this model, perceived convenience, perceived usefulness and perceived safety of the independent variables are study and dependent variable in this study is the use of internet banking services by customers that the theory of rationality is between the Fishbein and Ajzen, including both individual attitudes and behavior than intellectual norms. Indeed the research for the development of internet banking services and a better assessment of needs and demands of customers and to answer is the following main question:

"Whether a different level of internet banking services on the behavioral tendency to use these services varies by customer?”

Conceptual research model is as follows:

$<$ Figure 1 about here $>$

\section{Define and Concept of Electronic Banking:}

Electronic banking channels include all electronic that customers use for access their accounts and pay bills or transfer money from their. These channels include: telephone, internet, mobile and digital TV (lu.jetal,2003) in opinion of Manysh misra, electronic banking is the use of technology that to banks customers and other stakeholders to deal with bank without an intermediary bank through various channels such as internet, wireless devices, ATM and branches of the physical. In many cases, electronic banking and internet banking call virtual banking. And this is to do as virtual banking and far from bank branches. In other words is the virtual banking of presented banking services to help new it tools and different from their traditional banking, different ways that devices is done such as ATMs, telephone banking, internet and home. ( Liao et al ,63-74) electronic banking is in many ways similar to traditional payment methods. This is an important difference with traditional system that allows customers to have access to information and its banking operations and transactions do regardless of the location and use of personal computers and software and telecommunications networks. It is clear that the technologies enable customers through easy access to information is comparable. This allows customers to click with a mouse, to change service providers. (Durhin et al.,2003)

\section{Variety of Electronic Service Delivery Channels}

\subsection{Internet Banking}

The advent of internet has great impact on the electronic banking. By using internet, banking is no time limit and geographic. Customers worldwide can within 24 days of the week and all have access to their accounts. Internet banking by using internet and web technologies enable customers to finance their activities in a virtual environment to do this is the difference between internet banking and home banking that for achieving banking services via the internet, there is no need to install proprietary software rather banking services but also can be accessed via a internet public network and the customer is linked to your bank account via the internet. This type of banking is partially web-based banking subsidiary with the difference is that web banking services bank was considered first introduced bank and service. Internet banking also expanded with the development of web applications. With increasing internet access to people who provide these services to be developed and banks that are unresponsive to this issue will disappear from the market. (Liao et al, 1999) 


\subsection{Home Banking}

One type of electronic banking services is home banking or home banking. In this type of banking is done access to account information and banking services through a personal computer using a modem and a phone line in addition, a financial software or banking.

\subsection{Web Pages}

Currently, many organizations invest in create their own websites to deliver marketing messages. Now 63 percent of all businesses in England are having their own website. (waiteetal,2004). The easiest form of internet banking in order to display information about the products and services are via the network of World Wide Web. Today, all major banks and financial institutions have web pages. These pages allow customers and banks to interact and exchange information in order to provide. Also the web used as a tool for examining and received suggestions from customers and the development of communications and expansion services like e-mail. (Daniel et al.,1999).

\subsection{Telephone Banking}

One of the most common patterns of banking is telephone banking that it has long been used. There are generally three types of telephone banking system. A type of it automatically through a computer system is responsive. The other type, the telephone banking is based on operator. In this case the customer is a person responsible for the responders and guidance. Another type of telephone banking is based Personal computer that used a pc for contact system. Means someone using your computer is connected to the banking system.(liao et al.,1999)

Many services can be received through telephone banking such as bills, demand note requests, transfer funds between customer accounts in different banks, the second payment, received financial advice that typically are provided by human operators system. The availability of this phone can be very useful for everyone.(essinger,1999)

\subsection{Television Banking}

In this method, using satellite TV customers delivers account information on its TV screen. The main point is that these services did not require the use of personal computers and this encourages the development of market systems. People like TV. This is an advantage for these services.

\subsection{Mobile Banking}

Also, the concepts developed regarding electronic banking through mobile banking This approach has in fact developed internet banking and home banking (Hasanzadeh, 2003, p7). Mobile banking can be defined as a channel where customers can interact with the bank via a mobile device. In fact the financial services sector of the wireless internet to a digital input is possible and internet banking has expanded the concept to the mobile world. Mobile banking application used in two ways with Sms (Sms banking) and internet .The result is fast delivery of new services are more efficient on the customers and banks. (Okhovatpur, 2008,p85)

\subsection{ATM}

ATM machines is one of the first approaches electronic banking that emerged in the early stages of development of banking. The machines many make many banking services in day and night and customers using a personal identification number take on its financial transactions. Using cards and personal identification number, customers can receive and transfer money between accounts and pay or to obtain information about your account and billing application. Transactions conducted electronically as well, and are recorded immediately (Liao et al., 1999).

$$
<\text { Table1 about here }>
$$

\section{Research Hypotheses}

H1: Different levels effect of perceived ease on behavioral tendency to use is different internet banking service by customers.

H2: Different levels effect of perceived usefulness on behavioral tendency to use is different internet banking service by customers.

H3: different levels Effect of perceived security on the behavioral tendency to use is different internet banking service by customers.

\section{Research Methodology}

The scope of the research subject, in the field of consumer behavior. Scope of time has been studied in the second half of 2010 and first quarter of 2011. The location of study has been conducted in the Ardebil of Iran, users of internet banking system (Saba), Iran Melli bank. The purpose of this research is applicable and the study collected data from survey and the 
data analysis is from the correlation. The population study of all branches of Melli bank customers in Ardabil province is 89 - 90 year that use the internet banking system (Saba). The sample size for this study, based on the Cochran formula sample was 384.

Calculated sample size in this study is the following:

$$
n=\frac{z^{2} \alpha / 2}{\varepsilon^{2}} \times(P \cdot q)=\frac{\left(1.96^{2}\right)}{\left(0 / 05^{2}\right)} \times(0 / 5 \times 0 / 5) \cong 384
$$

In this study use of cluster sampling .First list of the cities of Ardabil province were listed and with cluster sampling selected five cluster and among clusters randomly two branches and in the end 10 branches were selected from among all clusters.

In this study, according to the standard questions are Before its validity is obtained questionnaire was used in this study were taken from the adjusted model, technology acceptance Davis, 1989 And other features and is set to provide customers an option.

For ensure that getting the best results, was evaluated validity and reliability. Cronbach coefficient were obtained of questions using the by software Spss Because Cronbach coefficient is optimal above $70 \%$ It can be inferred that the questionnaire used in the study, the reliability is higher.

\section{Data Analysis}

Descriptive results showed that the gender of the total 384 samples under study in Ardabil province, approximately 71 percent male and 29 percent are women. The average age of 31, this shows the age group of young. Education of respondents indicated that nearly 13 percent of those graduates, 39 percent of diplomas and the rest, about 47 percent college had, these results show the majority of graduates. The skills of working with computers, nearly 76 percent of patients with good computer skills and have modest and only 9 percent of people with computer skills were weak.

The results of testing hypotheses in the table follow:

\section{$<$ Table 2 about here $>$}

Statistical data of the table (3) can be calculated according to the grade level score of 0 / 05 is meaningful. Thus, assuming equal effectiveness between the surfaces can be rejected. Thus all of three research hypothesis is confirmed. The effect of different levels of (perceived ease, perceived usefulness, perceived safety) on the behavioral tendency to use different internet service banking by customers.

$$
<\text { Table } 3 \text { about here }>
$$

Friedman's test with significance level less than $05 / 0$ is the behavioral tendency to prioritize the factors affecting the use of Internet services banking are The primary useful of being perceived by customers With an average of 83 / 2, Second, perceived ease With an average of 74 / 1, And perceived safety in the third With an average of $43 / 1$.

\section{Conclusions and Suggestions}

Need to identify factors that affect the tendency of people to use internet banking service is required, because help to the banking industry in developing marketing strategies to promote new forms of electronic banking systems to meet customer needs. So the study conducted and the results of hypothesis testing can be offered the following suggestions.

The magnitude of perceived ease, perceived usefulness and perceived security by customers is higher that they will be more tend to use electronic banking services. Therefore, banks should try to strengthen following cases:

1) Simplify web design services, internet banking.

2) Simplify and shorten the process and conduct banking transactions.

3) Easy access to electronic banking tools such as internet.

4) Advertising continued to acquaint customers with the tools and services, electronic banking and get their opinions toward user-friendly system.

5) Most of the branches provide banking services offered through the electronic banking system. 
6) Increased speed of transactions conducted through electronic systems that actually save time and the customer will notice that the transactions done through electronic systems rather than stands in long queues in branches and has superior advantage.

7) Inform customers of security issues and standards compliance by the bank to increase public awareness of the security (if the customer is notified of potential security of the bank to be created in a popular security)

8) Discussion of financial insurance against any possible abuse of the internet and in the wrong patient receives funds paid or to be taken seriously until future development of these systems and enhance customer awareness, increases their tendency to use electronic banking services.

\section{References}

Abasinejad,h,mehrnoosh,m.(2006). electronic banking,samt publisher, First Printing.

Ahmad,A.,humayoun,A.,Nawaz,M.(2011). How Customer Satisfaction affects Performance of Islamic Banks in Pakistan, Journal of Contemporary Research in business, VOL2,NO9.

Ajzen.(2002). Behavioral Interventions Based on the Theory of Planned Behavior, Journal of the Association for Information Systems.

Alam,H.,Arsalan,M.,Saleem,M.,Raziq,H.,Alee,A.(2011). Development of Islamic Banking in Pakist, Journal of Contemporary Research in business,VOL3,NO1.

Baiat,m.(2008). Electronic Banking and Central Bank, Electronic Banking.

Barnard.L,Vansolms.r.(2002). The Evaluation and certification of information security against BS7799,information management and computer security,vol6,no2-3,pp72-77.

Chang.h.c.(2006). Exploring the digital capital indicators of Internet Banking in Taiwan , journal of American Academy of Business,9(1),pp210-213.

Daniel , E. , Stovey , ch.(1999). online banking : strategic and management for competitive advantages , Singapore , Mc Growhil.

Davis f . , Bagozzi , R . , Warshaw, p.(1989). User acceptance of computer technology: a comparison of two theoretical models .

Durkin , M.,Howcroft , B.(2003). Relationship marketing in the banking sector, marketing Intelligence and planning, vol 27.

Essinger , J.(1999). the virtual banking revolution , the customer , the bank and the future , international Thomson business press.

Hasanzadeh.(2003).electronic banking, New economy.

Katariina Ma enpa a., Sudhir H. Kaleb., Hannu Kuuselaa, Nina Mesiranta.(2008). Consumer perceptions of Internet banking in Finland: The moderating role of familiarity, Journal of Retailing and Consumer Services 15,pp 266-276

Lassar.w.,Manolis.c.,Lassar.s.(2005). the relationship between consumer innovativeness, personal characteristics, and on-line banking adoption "International journal of bank marketing,VOL23,NO2,pp176-199.

Laukkanen.t.(2007). Internat VS mobile banking: comparing customer value perceptions "Business process management journal,VOL13,NO6,pp788-797.

Liao, sh., pushao, Y., wang , H., Chen ,A . (1999). the adoption of virtual banking : an empirical study , International Journal of information management.

LU .J. ,L iu,c., Yao,J.(2003). Technology Acceptance Model for wireless internet ，Electronic Networking Applications and policy, vol 13, No3.

Mattila.m.,Karjaluoto.h.,Pento.t.(2003). Internet banking adoption among mature customers: early majority or laggards? , journal of services marketing,VOL17,NO5,pp514-528.

Moradian,h.(2004). electronic banking and others experience, Business Monthly,118

Okhovat poor,b.(2008). Position of mobile in e-banking, Radiation Nation

Pikkarainen.t,Pikkarainen.k,karjaluoto.Hand pahnila.s.(2004). Consumer acceptance of on-line banking:an extension of the technology acceptance model, Internet Research,VOL14,NO3,pp224-235.

Rugimbana.R.(2007).’The relationship between values and personal e-banking service preferences ,International of Banking marketing, VOL25,NO1,pp6-21.

Sohail.m.s.,sheikh.n.m.(2008). Internet banking and quality of service, on line information Review,VOL32,NO1,pp58-72. 
Waite ,k.,Harrison , T.(2004). online banking information : what we want and what we get , Qualitative Market Research : An International Journal , vol 7 , no1.

Wang , Y., wang., Lin , H., Tang , T. (2003). Determinants of user acceptance of internet banking : an empirical study , International Journal of service Industry Management.

Yiu.c.s,Grant.k,Adgar.d.(2007). Factors affecting the adoption of Internet Banking in Hong kong-implication for the banking sector” International Journal of Information management,27,336-351.

Table 1. Research on e-banking

\begin{tabular}{|c|c|c|}
\hline Scholar & Topic & Result \\
\hline $\begin{array}{l}\text { Bander Alsajjan } \\
\qquad(2010)\end{array}$ & $\begin{array}{l}\text { Internet banking acceptance model: } \\
\text { Cross-market examination }\end{array}$ & $\begin{array}{c}\text { The Internet banking acceptance model is robust } \\
\text { and parsimonious, explaining over } 80 \% \text { of } \\
\text { attitudinal intentions }\end{array}$ \\
\hline $\begin{array}{l}\text { Chi Shing Yiu \& et al } \\
\text { (2007) }\end{array}$ & $\begin{array}{l}\text { Factors affecting the adoption of } \\
\text { Internet Banking in Hong } \\
\text { Kong_-implications for the banking } \\
\text { sector }\end{array}$ & $\begin{array}{l}\text { Certain factors did have a positive relationship } \\
\text { with the adoption of Internet Banking and as such } \\
\text { strategy in the banking services sector can be } \\
\text { refined to better meet the demands and profile of } \\
\text { the Hong Kong market. }\end{array}$ \\
\hline $\begin{array}{l}\text { Katariina Ma“ enpa“ } \\
\text { (2008) }\end{array}$ & $\begin{array}{l}\text { Consumer perceptions of Internet } \\
\text { banking in Finland: The moderating } \\
\text { role of familiarity }\end{array}$ & $\begin{array}{l}\text { level of IB familiarity impacted four out of seven } \\
\text { service dimensions explored in the } \\
\text { research. These findings may provide useful } \\
\text { guidelines for developing Internet bank services } \\
\text { and for marketing Internet banking }\end{array}$ \\
\hline Lassar.w \& et al(2005) & $\begin{array}{l}\text { the relationship between consumer } \\
\text { innovativeness ,personal } \\
\text { characteristics, and on-line banking } \\
\text { adoption }\end{array}$ & $\begin{array}{l}\text { Positive relationship between public innovation } \\
\text { and the innovation they show }\end{array}$ \\
\hline Laukkanen.t(2007) & $\begin{array}{l}\text { Internet VS mobile banking : } \\
\text { comparing customer value perceptions }\end{array}$ & $\begin{array}{c}\text { Increased business managers about the perceived } \\
\text { value of electronic banking channels for Measures } \\
\text { to increase the acceptance by customers of } \\
\text { banking channels. }\end{array}$ \\
\hline $\begin{array}{l}\text { Mattila.m,Karjaluoto.h } \\
\text {,Pento.t,(2003) }\end{array}$ & $\begin{array}{l}\text { Internet banking adoption among } \\
\text { mature customers }\end{array}$ & $\begin{array}{l}\text { The problems of lack of computers with personal } \\
\text { e-banking services as the main barrier to Internet } \\
\text { banking adoption among mature customers were } \\
\text { discovered. }\end{array}$ \\
\hline $\begin{array}{l}\text { Pikkarainen.t \& et al } \\
\text { (2004) }\end{array}$ & $\begin{array}{l}\text { Consumer acceptance of on-line } \\
\text { banking }\end{array}$ & $\begin{array}{l}\text { Perceived usefulness and information on the } \\
\text { banking - online banking website, two factors } \\
\text { accepted it on on-line banking }\end{array}$ \\
\hline Rugimbana.R,(2007) & $\begin{array}{l}\text { The relationship between values and } \\
\text { personal e-banking service } \\
\text { preferences }\end{array}$ & $\begin{array}{l}\text { Outstanding cultural values such as character } \\
\text { reference group pressure, self-esteem and social } \\
\text { identity influence the likelihood that the } \\
\text { acceptance of electronic banking channels. }\end{array}$ \\
\hline $\begin{array}{l}\text { Sohail.m.s \& et al } \\
\qquad(2008)\end{array}$ & $\begin{array}{l}\text { Internet banking and quality of } \\
\text { service }\end{array}$ & $\begin{array}{c}\text { Three factors affect the assessment of users of } \\
\text { Internet banking service quality And the factor can } \\
\text { be 'efficiency and safety "and" satisfaction and } \\
\text { consistency " }\end{array}$ \\
\hline Wang , Y(2003) & $\begin{array}{l}\text { Determinants of user acceptance } \\
\text { of internet banking : }\end{array}$ & $\begin{array}{l}\text { The effectiveness of computer oriented behavior } \\
\text { through perceived ease of use, perceived } \\
\text { usefulness and perceived credibility }\end{array}$ \\
\hline
\end{tabular}


Table 2. ANOVA test

\begin{tabular}{|c|c|c|c|c|c|}
\hline Hypotheses & Sum of squares & $\mathrm{df}$ & Mean square & $\mathrm{F}$ & Sig \\
\hline H1 & 277.015 & 2 & 138.508 & 9.376 & 0.000 \\
\hline H2 & 899.299 & 2 & 449.650 & 34.221 & 0.000 \\
\hline H3 & 460.792 & 2 & 230.396 & 16.122 & 0.000 \\
\hline
\end{tabular}

Table 3. Friedman test for levels of perceived customer ratings

\begin{tabular}{|c|c|c|c|c|}
\hline Behavioral factors affecting trends & Mean rank & Chi-square & df & Sig \\
\hline Perceived ease & 1.74 & & 2 & 0.000 \\
\cline { 1 - 2 } Perceived usefulness & 2.83 & \multirow{2}{*}{439.729} & & \\
\cline { 1 - 2 } Perceived security & 1.43 & & & \\
\hline
\end{tabular}

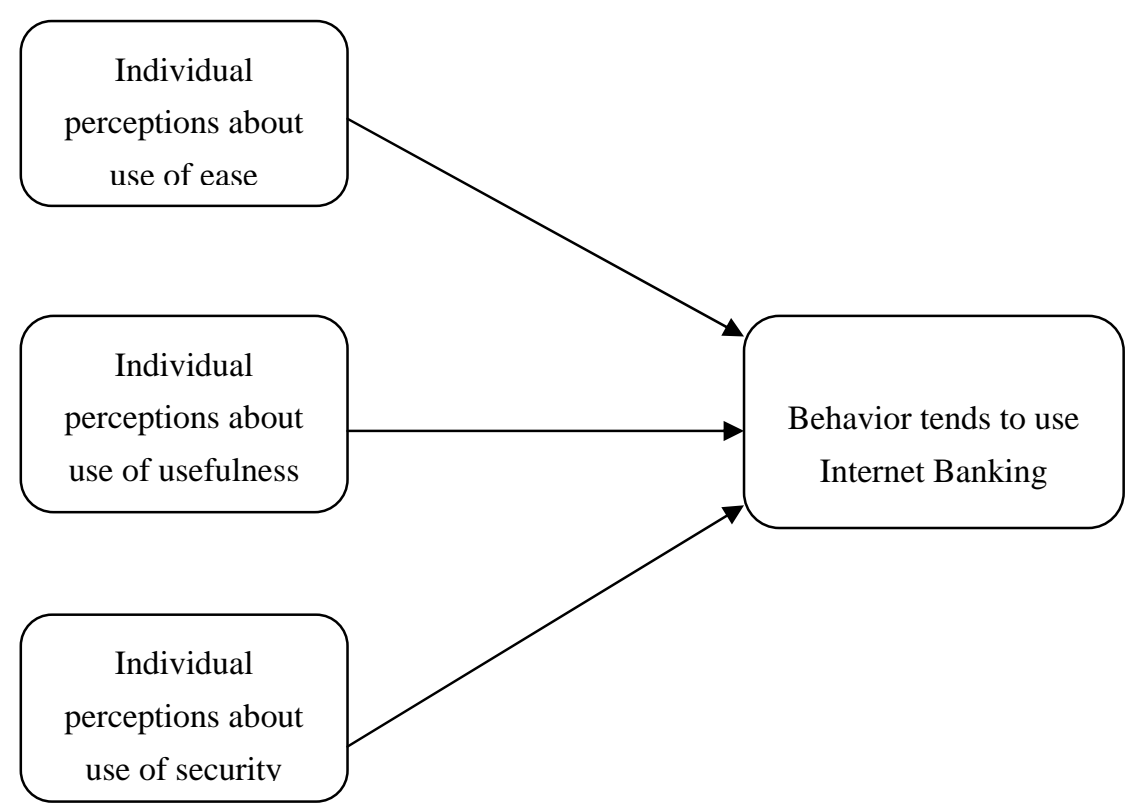

Figure 1. Adjust the technology acceptance model, Davis, 1989 